Supporting information

\title{
Ratiometric imaging of cysteine level changes in endoplasmic reticulum during $\mathrm{H}_{2} \mathrm{O}_{2}$-induced redox imbalance
}

\author{
Baoli Dong, Yaru Lu, Nan Zhang, Wenhui Song and Weiying Lin* \\ Institute of Fluorescent Probes for Biological Imaging, School of Chemistry and Chemical \\ Engineering, School of Materials Science and Engineering, University of Jinan, Jinan, Shandong \\ 250022, People's Republic of China
}

\section{Corresponding Author}

* E-mail: weiyinglin2013@163.com. 


\section{Table of contents}

Page

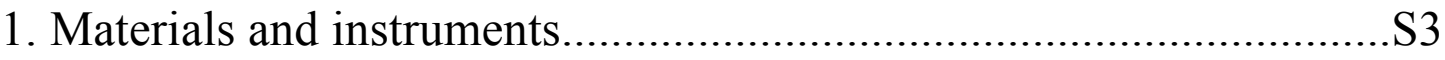

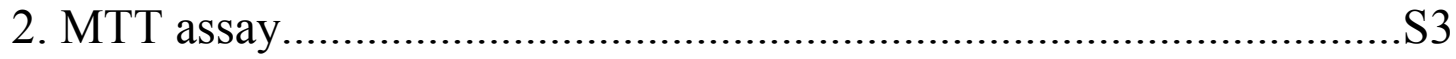

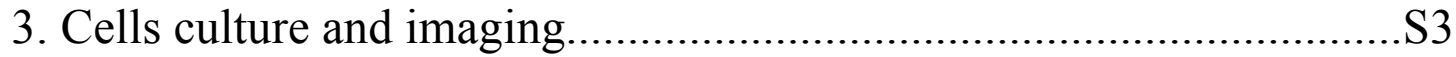

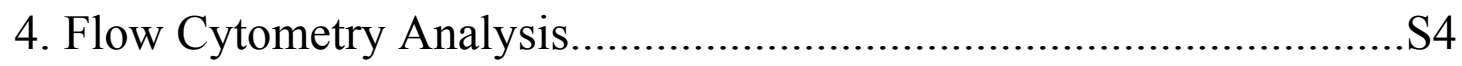

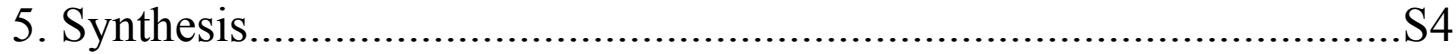

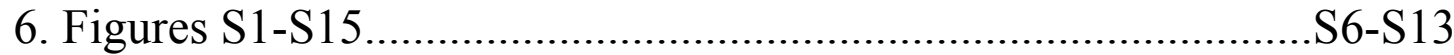

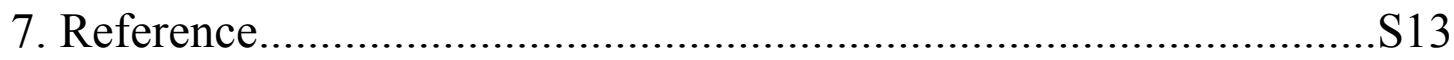


Materials and instruments: All solvents and reagents were commercially available and used without further purification. Doubly distilled water was used in all the experiments. Thin-layer chromatography (TLC) analysis was performed on silica gel plates and column chromatography was conducted over silica gel (mesh 200-300), both of which were purchased from the Qingdao Ocean Chemicals. Xanthine oxidase from bovine milk was pruchased Sigma Company. Fluorescence spectra and relative fluorescence intensity were measured with a Hitachi F-4600 spectrofluorimeter with a $10 \mathrm{~mm}$ quartz cuvette. UV/vis spectra were obtained with a Shimadzu UV-2700 spectrophotometer. High-resolution mass spectra (HRMS) for the characterization of structures were collected using a Bruker apex-Ultra mass spectrometer (Bruker Daltonics Corp., USA) in electrospray ionization (ESI) mode. ${ }^{1} \mathrm{H}$ and ${ }^{13} \mathrm{C}$ NMR spectra were recorded on an AVANCE III $400 \mathrm{MHz}$ Digital NMR Spectrometer, using DMSO-d6 as solvent and tetramethylsilane (TMS) as internal reference. Liquid chromatography/mass spectrometry (LC-MS) analysis was performed from Agilent 6400 series Triple Quadrupole using an ESI mass spectrometer.

MTT assay: The cytotoxicity of Nap-Cys was evaluated in HeLa cells using MTT assays. The cells were seeded into 96-well plates with a density of 5000 cells per well, and then treated without (control experiment) or with various concentrations of NapCys added. After culturing overnight at $37{ }^{\circ} \mathrm{C}, 20 \mu \mathrm{L}$ of freshly prepared MTT solution (5 mg.mL $\mathrm{mL}^{-1}$ in PBS) and $180 \mu \mathrm{L}$ medium were added to each well, and then the cells were incubated for another $4 \mathrm{~h}$. Subsequently, the medium was removed, and the purple products were lysed in $200 \mu \mathrm{L}$ DMSO. The plates were shaken for $20 \mathrm{~min}$ and the absorbance was measured at $570 \mathrm{~nm}$ by a Perkin-Elmer Victor plate reader.

Cells culture and imaging: HeLa cells were cultured in Dulbecco's modified eagle medium (DMEM) medium supplemented with 10\% FBS (fetal bovine serum) and incubated at $37^{\circ} \mathrm{C}$ in air atmosphere $\left(5 \% \mathrm{CO}_{2}\right)$.

(1) Colocalization experiments: The HeLa cells were seeded into glass bottom dishes with appropriate density. After $24 \mathrm{~h}$, the cells were treated with $5 \mu \mathrm{M}$ probe Nap-Cys for $30 \mathrm{~min}$, and then treated with $1 \mu \mathrm{M}$ ER-tracker Red (or $1 \mu \mathrm{M}$ MitoTraker Red, or $1 \mu \mathrm{M}$ LysoTracker Red) for $10 \mathrm{~min}$. Fluorescence images were acquired with Nikon A1R confocal microscope with a $100 \times$ objective lens. 
(2) Fluorescence imaging of endogenous cysteine: (A) HeLa cells treated with $5 \mu \mathrm{M}$ Nap-Cys for $20 \mathrm{~min}$, rinsed for three times with PBS, and then the cells were imaged; (B) HeLa cells pretreated with $1 \mathrm{mM}$ NEM for $30 \mathrm{~min}$ and then treated with $5 \mu \mathrm{M}$ Nap-Cys for $20 \mathrm{~min}$, rinsed for three times with PBS, and then the cells were imaged; (C) HeLa cells pretreated with $1 \mathrm{mM}$ NEM for $30 \mathrm{~min}$, rinsed for three times with PBS and then treated with $100 \mu \mathrm{M}$ Cys for $30 \mathrm{~min}$. Subsequently cells were incubated with $5 \mu \mathrm{M}$ Nap-Cys for $20 \mathrm{~min}$, rinsed for three times with PBS, and then the cells were imaged. Fluorescence images were acquired with Nikon A1R confocal microscope with a $100 \times$ objective lens.

(3) Fluorescence imaging of cysteine level changes during $\mathrm{H}_{2} \mathrm{O}_{2}$-induced redox imbalance: The HeLa cells were seeded into glass bottom dishes with appropriate density. After $24 \mathrm{~h}$, the cells were treated with $200 \mu \mathrm{M}$ or $400 \mu \mathrm{M} \mathrm{H}_{2} \mathrm{O}_{2}$ for $20 \mathrm{~min}$, and washed three times with PBS (pH 7.4). Then, the cells were incubated with $5 \mu \mathrm{M}$ Nap-Cys at $37^{\circ} \mathrm{C}$ for different time, and washed three times with PBS (pH 7.4) to remove excess extracellular Nap-Cys. Fluorescence images were acquired with Nikon A1R confocal microscope with a $100 \times$ objective lens.

Flow Cytometry Analysis: The cells were cultured in 6-well plates, and then treated with probes as described in the work. After harvest, cells were washed and suspended in fresh complete medium and analyzed by flow cytometry (Gallios, Beckman coulter). For blue channel: $\lambda_{\mathrm{ex}}=405 \mathrm{~nm}$; green channel: $\lambda_{\mathrm{ex}}=488 \mathrm{~nm}$.

\section{Synthesis}

1. Synthesis of Nap-OH
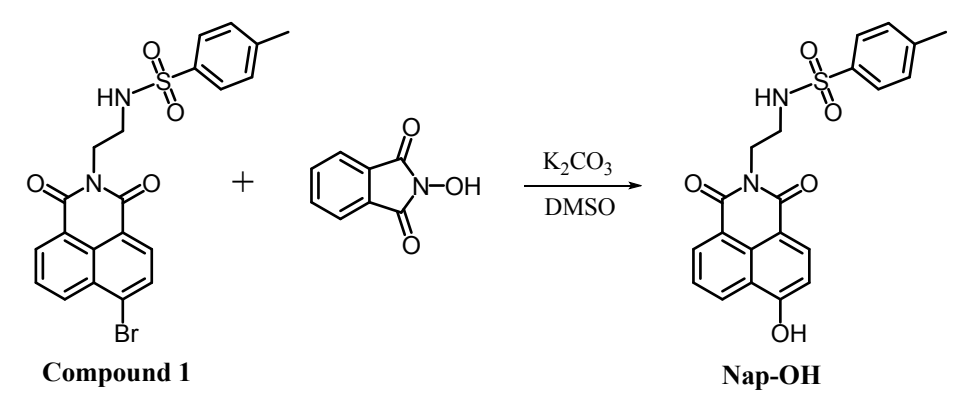
Compound $\mathbf{1}^{1}$ (118 mg, $0.25 \mathrm{mmol}$ ), 2-hydroxyisoindoline-1,3-dione (49 mg, 0.3 mmol) and $\mathrm{K}_{2} \mathrm{CO}_{3}(52 \mathrm{mg}, 0.38 \mathrm{mmol})$ were dissolved in $2 \mathrm{~mL} \mathrm{DMSO}$, and the mixture was vigorously stirred at $120{ }^{\circ} \mathrm{C}$ for $5 \mathrm{~h}$. after the reaction, the mixture was cooled to room temperature and poured into $5 \mathrm{~mL}$ cold water, and then acidified by $\mathrm{HClO}_{4}$ until the solid product precipitated out. The precipitated solid was filtered, dried under a vacuum, and purified by column chromatography $\left(\mathrm{CH}_{2} \mathrm{Cl}_{2}: \mathrm{MeOH}=\right.$ 20:1) afford Nap-OH as a yellow solid $(56 \%, 57 \mathrm{mg}) .{ }^{1} \mathrm{H}$ NMR $\left(\mathrm{CDCl}_{3}\right.$ :Methanol- $d_{4}$, $\mathrm{v}: \mathrm{v}=1: 1,400 \mathrm{MHz}): \delta 8.58(\mathrm{dd}, 1 \mathrm{H}), 8.43(\mathrm{~d}, J=7.2,1 \mathrm{H}), 8.30(\mathrm{~d}, J=8.4,1 \mathrm{H})$, $7.65(\mathrm{t}, 1 \mathrm{H}), 7.49$ (d, $J=8.4,2 \mathrm{H}), 7.02(\mathrm{~d}, J=8.0,1 \mathrm{H}), 6.79(\mathrm{~d}, J=7.2,2 \mathrm{H}), 4.19$ $(\mathrm{t}, 2 \mathrm{H}), 3.33(\mathrm{t}, 2 \mathrm{H}), 2.00(\mathrm{~s}, 3 \mathrm{H}) .{ }^{13} \mathrm{H} \mathrm{NMR}\left(\mathrm{CDCl}_{3}\right.$ : Methanol-d $d_{4}$, v:v = 1:1, 100 $\mathrm{MHz}): \delta 165.08,164.52,161.06,142.81,137.12,134.04,131.63,129.84,129.70$, 129.09, 126.35, 126.16, 122.81, 121.58, 109.56, 41.39, 39.01, 20.52. HRMS (ESI): $\mathrm{m} / \mathrm{z}$ calculated for $\mathrm{C}_{21} \mathrm{H}_{18} \mathrm{~N}_{2} \mathrm{O}_{5} \mathrm{~S}, 411.1009[\mathrm{M}+\mathrm{H}]^{+}$, found: 496.1760.

\section{Synthesis of Nap-Cys}
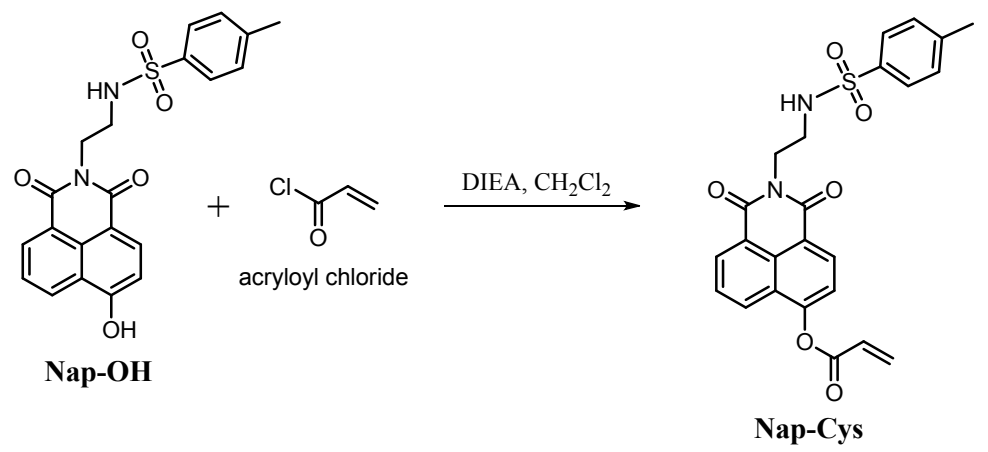

A mixture of Nap-OH (41 mg, $0.1 \mathrm{mmol}$ ), acryloyl chloride (27 mg, $0.3 \mathrm{mmol}$ ) and DIEA (13 mg, $0.1 \mathrm{mmol})$ in $3 \mathrm{~mL} \mathrm{CH}_{2} \mathrm{Cl}_{2}$ was stirred at room temperature for $2.5 \mathrm{~h}$. The reaction mixture was purified by column chromatography $\left(\mathrm{CH}_{2} \mathrm{Cl}_{2}: \mathrm{MeOH}=\right.$ 50:1) to afford Nap-Cys $(78 \%, 36 \mathrm{mg})$ as a yellow powder. ${ }^{1} \mathrm{H}$ NMR $\left(\mathrm{CDCl}_{3}, 400\right.$ MHz): $\delta 8.55(\mathrm{~d}, J=6.4,2 \mathrm{H}), 8.29(\mathrm{~d}, J=8.4,1 \mathrm{H}), 7.79(\mathrm{t}, 1 \mathrm{H}), 7.63(\mathrm{~d}, J=8.0,1$ H), $7.55(\mathrm{~d}, J=8.0,2 \mathrm{H}), 6.81(\mathrm{~d}, J=17.2,1 \mathrm{H}), 6.74(\mathrm{~d}, J=8.0,2 \mathrm{H}), 6.51(\mathrm{~m}, 1 \mathrm{H})$, $6.24(\mathrm{~d}, J=10.4,1 \mathrm{H}), 5.19(\mathrm{t}, 1 \mathrm{H}), 4.28(\mathrm{q}, 2 \mathrm{H}), 3.48(\mathrm{t}, 2 \mathrm{H}), 1.95(\mathrm{~s}, 3 \mathrm{H}) .{ }^{13} \mathrm{C}$ NMR $\left(\mathrm{CDCl}_{3}, 100 \mathrm{MHz}\right): \delta 164.42,163.39,163.54,151.78,142.84,136.94,134.58$, $132.04,131.93,129.34,129.22,128.11,127.32,126.92,126.69,125.19,122.40$, 
119.91, 119.55, 42.56, 39.17, 21.08. HRMS (ESI): $\mathrm{m} / \mathrm{z}$ calculated for $\mathrm{C}_{24} \mathrm{H}_{20} \mathrm{~N}_{2} \mathrm{O}_{6} \mathrm{~S}$, $465.1115[\mathrm{M}+\mathrm{H}]^{+}$, found: 465.1110 .

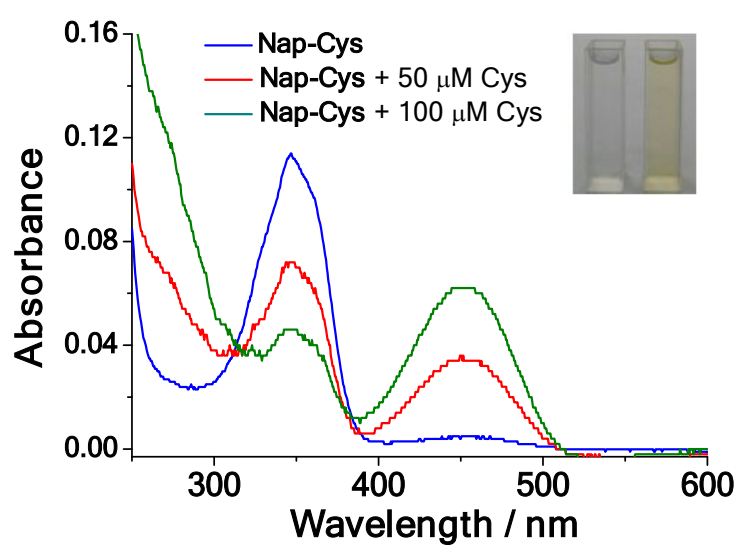

Figure S1 UV-Vis spectra of $5 \mu \mathrm{M}$ Nap-Cys in the absence and presence of Cys in PBS ( $\mathrm{pH}=7.4,10 \% \mathrm{EtOH}, 20 \mathrm{mM})$. Inset: Images of the probe in the absence (left) and presence (right) of $100 \mu \mathrm{M}$ Cys.

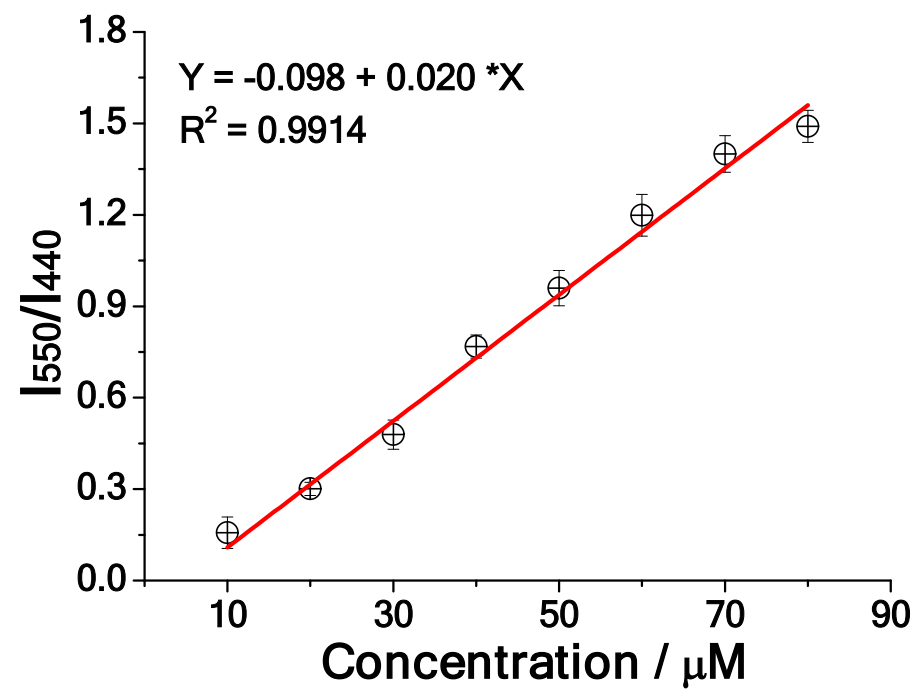

Figure S2 Linear relationship between $\mathrm{I}_{550} / \mathrm{I}_{440}$ and HA concentration in the range 10$80 \mu \mathrm{M} . \lambda_{\text {ex }}=395 \mathrm{~nm}$. 


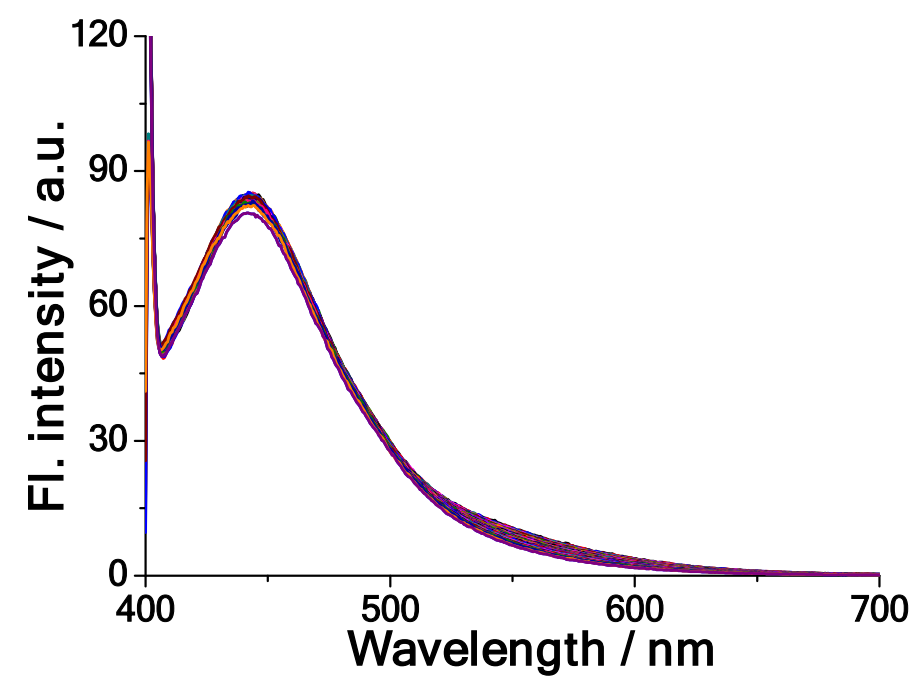

Figure S3 Time-dependent (0-40 min) fluorescence spectra of $5 \mu \mathrm{M}$ Nap-Cys under excitation at $390 \mathrm{~nm}$.

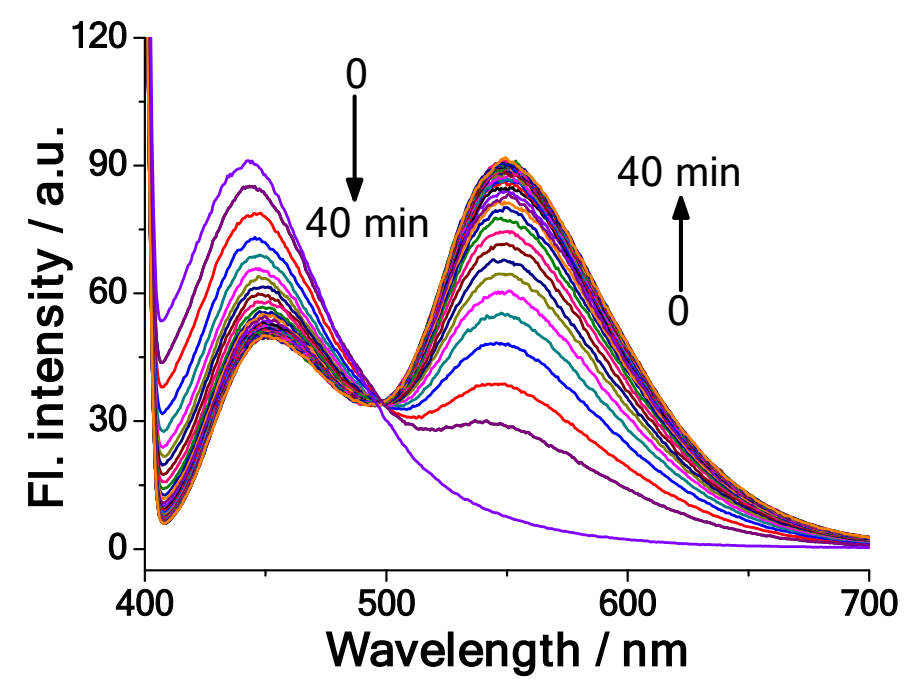

Figure S4 Time-dependent (0-40 min) fluorescence spectra of $5 \mu \mathrm{M}$ Nap-Cys in the presence of $100 \mu \mathrm{M}$ Cys under excitation at $390 \mathrm{~nm}$. 


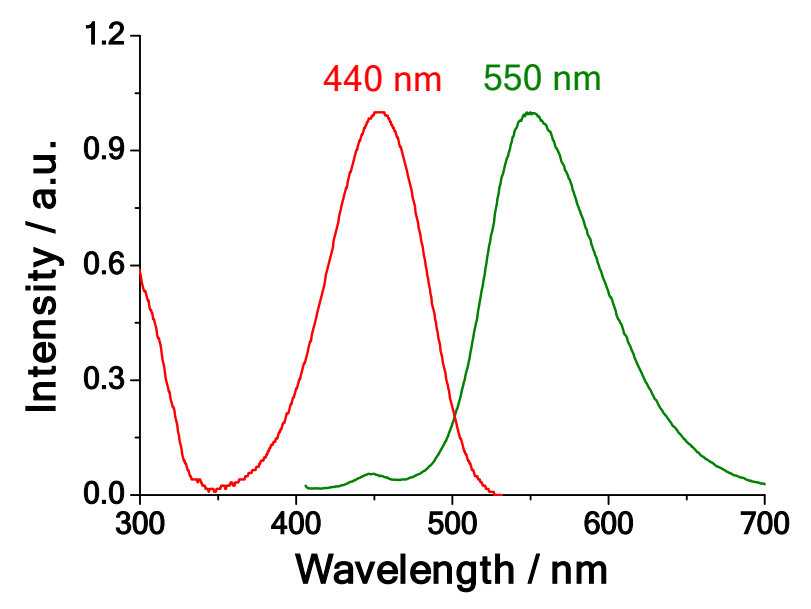

Figure S5 Normalized absorption and fluorescence spectra $\left(\lambda_{\mathrm{ex}}=390 \mathrm{~nm}\right)$ of $5 \mu \mathrm{M}$ Nap-OH in PBS (pH = 7.4, 10\% EtOH, $20 \mathrm{mM})$.

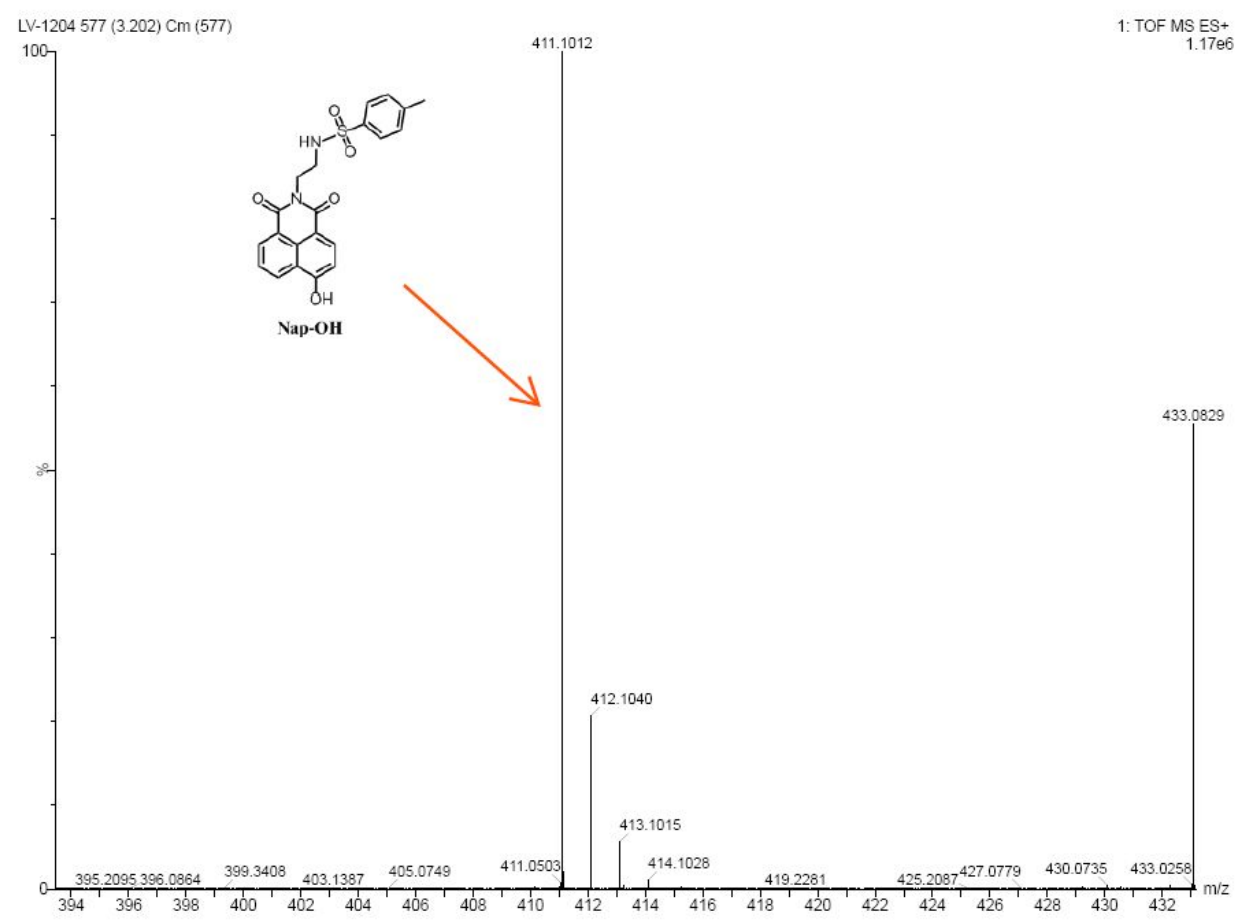

Figure S6 HRMS data of the reaction product of the probe Nap-Cys with Cys. 

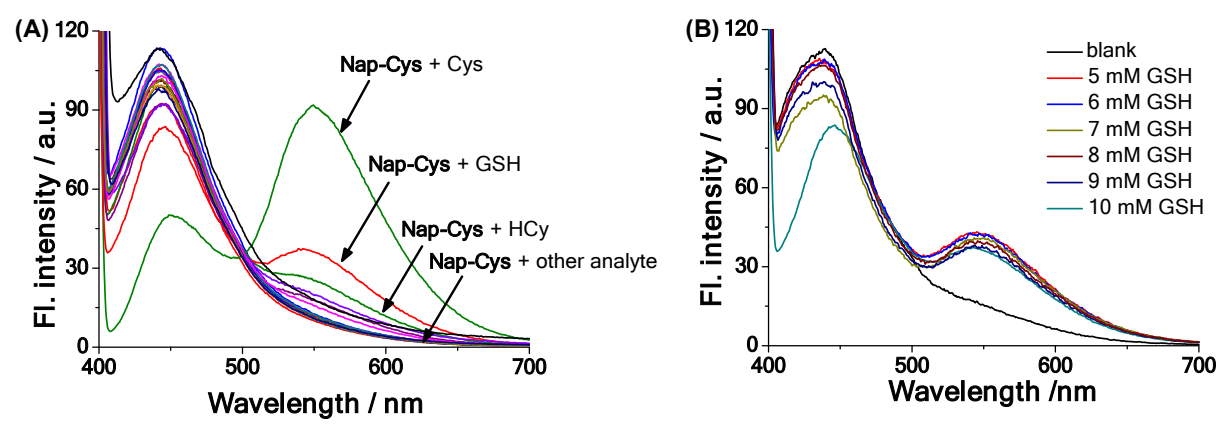

Figure S7 (A) Fluorescence spectra of $5 \mu \mathrm{M}$ Nap-Cys upon addition of various relevant analytes. Concentration: GSH, $10 \mathrm{mM}$; other analytes, $100 \mu \mathrm{M}$. (B) Fluorescence spectra of $5 \mu \mathrm{M}$ Nap-Cys upon addition of GSH with different concentrations. $\lambda_{\mathrm{ex}}=390 \mathrm{~nm}$.
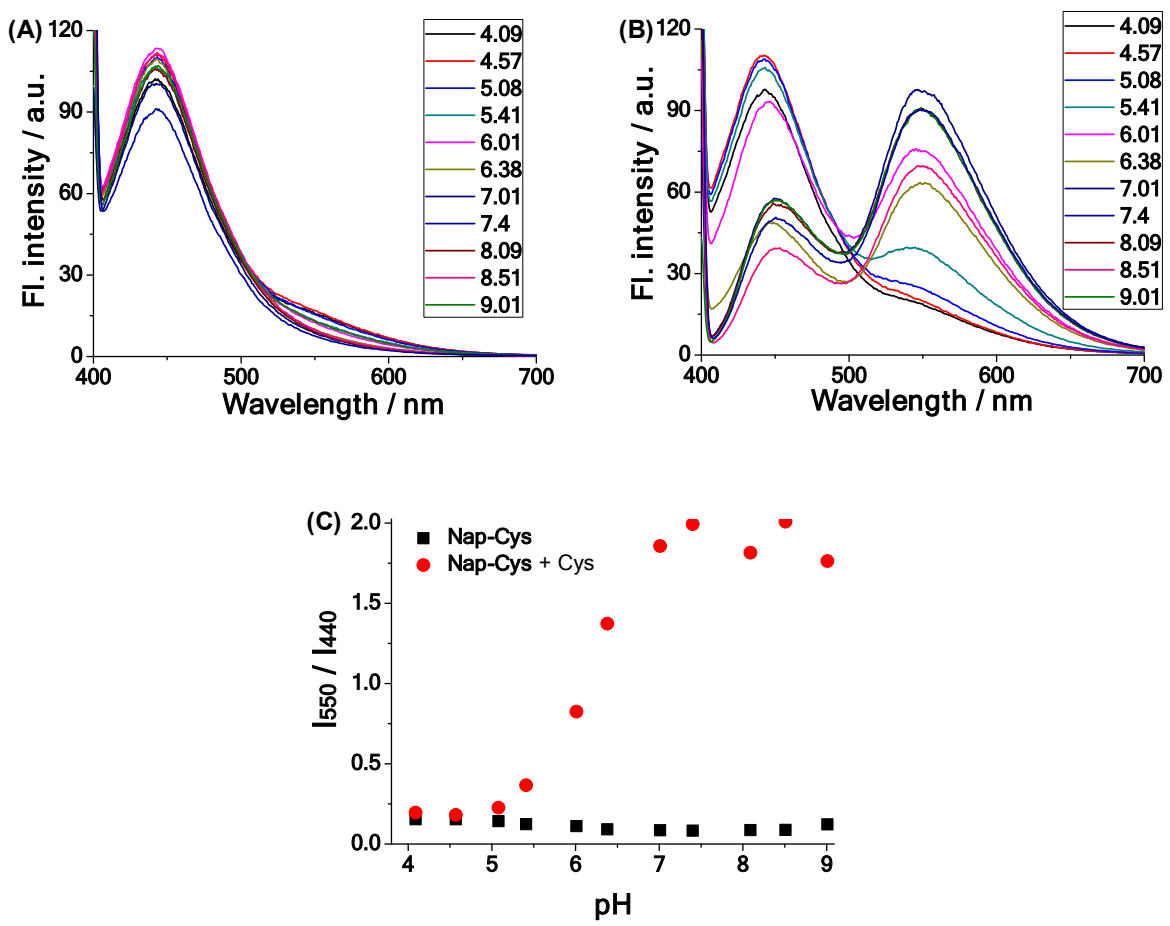

Figure S8 Fluorescence spectra of $5 \mu \mathrm{M}$ Nap-Cys in the absence (A) and presence (B) of $100 \mu \mathrm{M}$ Cys at various $\mathrm{pH}$ conditions. (C) Fluorescence intensity ratios $\left(\mathrm{I}_{550} / \mathrm{I}_{440}\right)$ of Nap-Cys in the absence (black) and presence (red) of $100 \mu \mathrm{M}$ Cys at various $\mathrm{pH}$ conditions. $\lambda_{\mathrm{ex}}=390 \mathrm{~nm}$. 


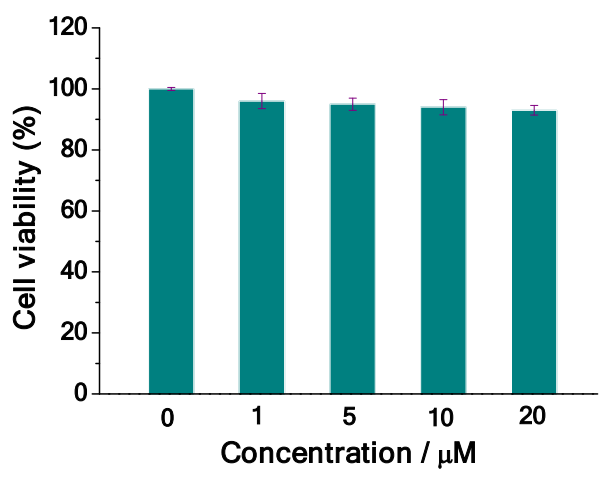

Figure S9 Survial of HeLa cells in the presence of Nap-Cys at various concentrations measured using MTT assay.
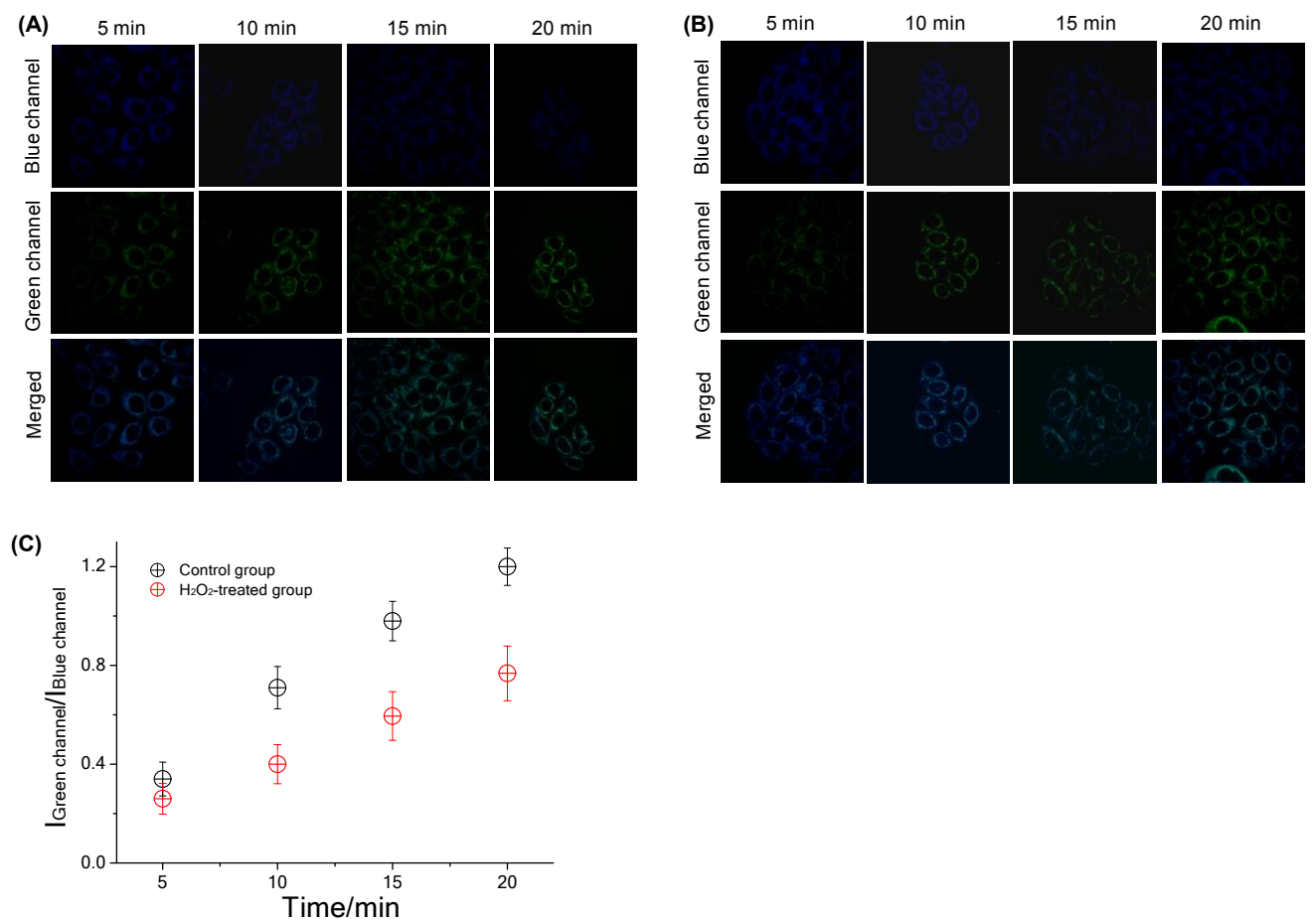

Figure S10 (A) HeLa cells treated with $5 \mu \mathrm{M}$ Nap-Cys for $5 \mathrm{~min}, 10 \mathrm{~min}, 15$ min and 20 min, respectively. (B) HeLa cells pretreated with $200 \mu \mathrm{M} \mathrm{H}_{2} \mathrm{O}_{2}$ for 20 min and then treated with $5 \mu \mathrm{M}$ Nap-Cys for $5 \mathrm{~min}, 10 \mathrm{~min}, 15 \mathrm{~min}$ and $20 \mathrm{~min}$, respectively. Blue channel: $\lambda_{\mathrm{em}}=425-475 \mathrm{~nm}$; Green channel: $\lambda_{\mathrm{em}}=500-550 \mathrm{~nm}$. $\lambda_{\text {ex }}=405 \mathrm{~nm}$. (C) The ratio of the fluorescence intensities in green channel and blue channel ( $\mathrm{I}_{\text {Green channel }} / \mathrm{I}_{\text {Blue channel }}$ ) for control group (A) and $\mathrm{H}_{2} \mathrm{O}_{2}$-treated group (B). 


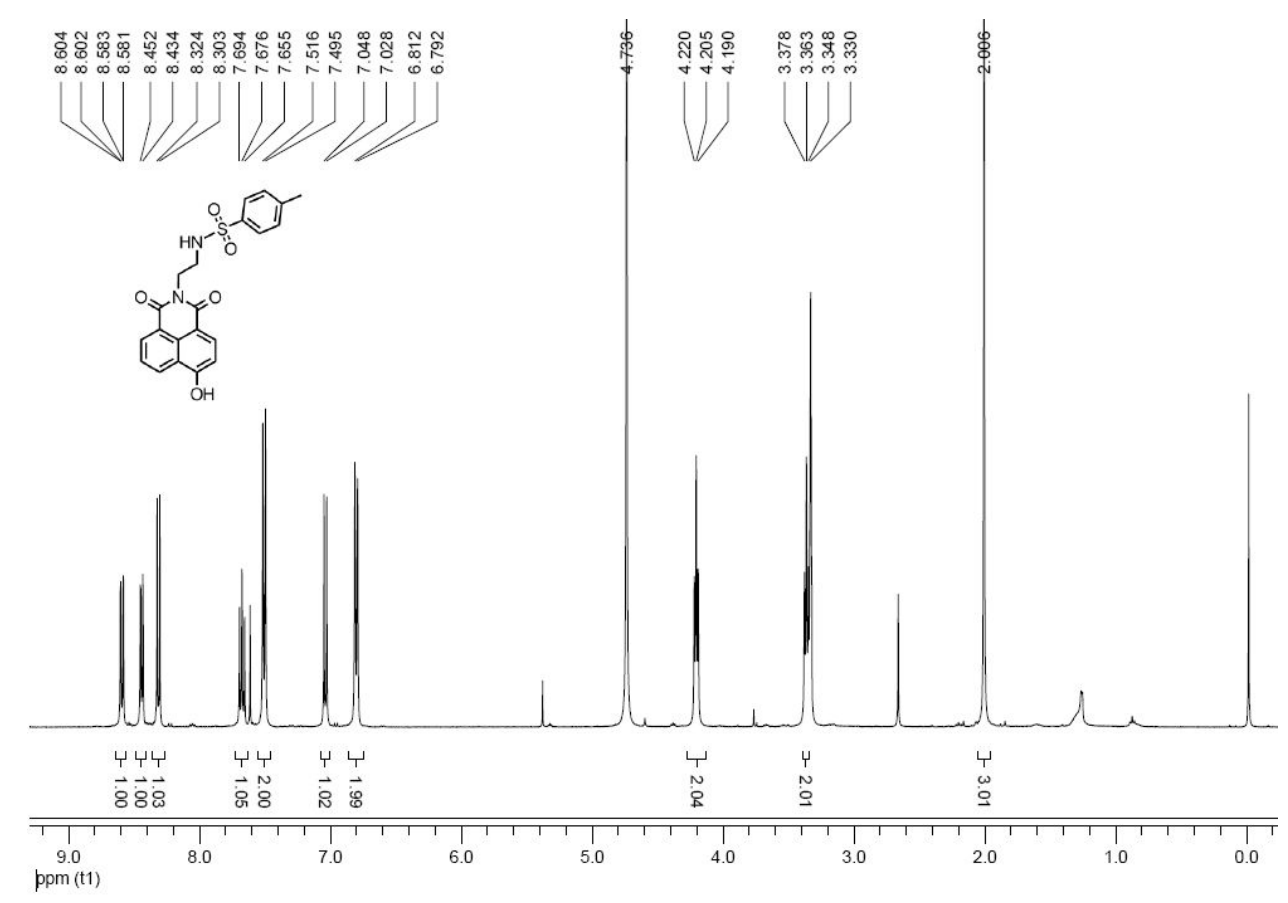

Figure $\mathbf{S 1 1}{ }^{1} \mathrm{H}$ NMR data of compound Nap-OH $\left(\mathrm{CDCl}_{3}: \mathrm{MeOD}, \mathrm{V}: \mathrm{V}=1: 1\right)$

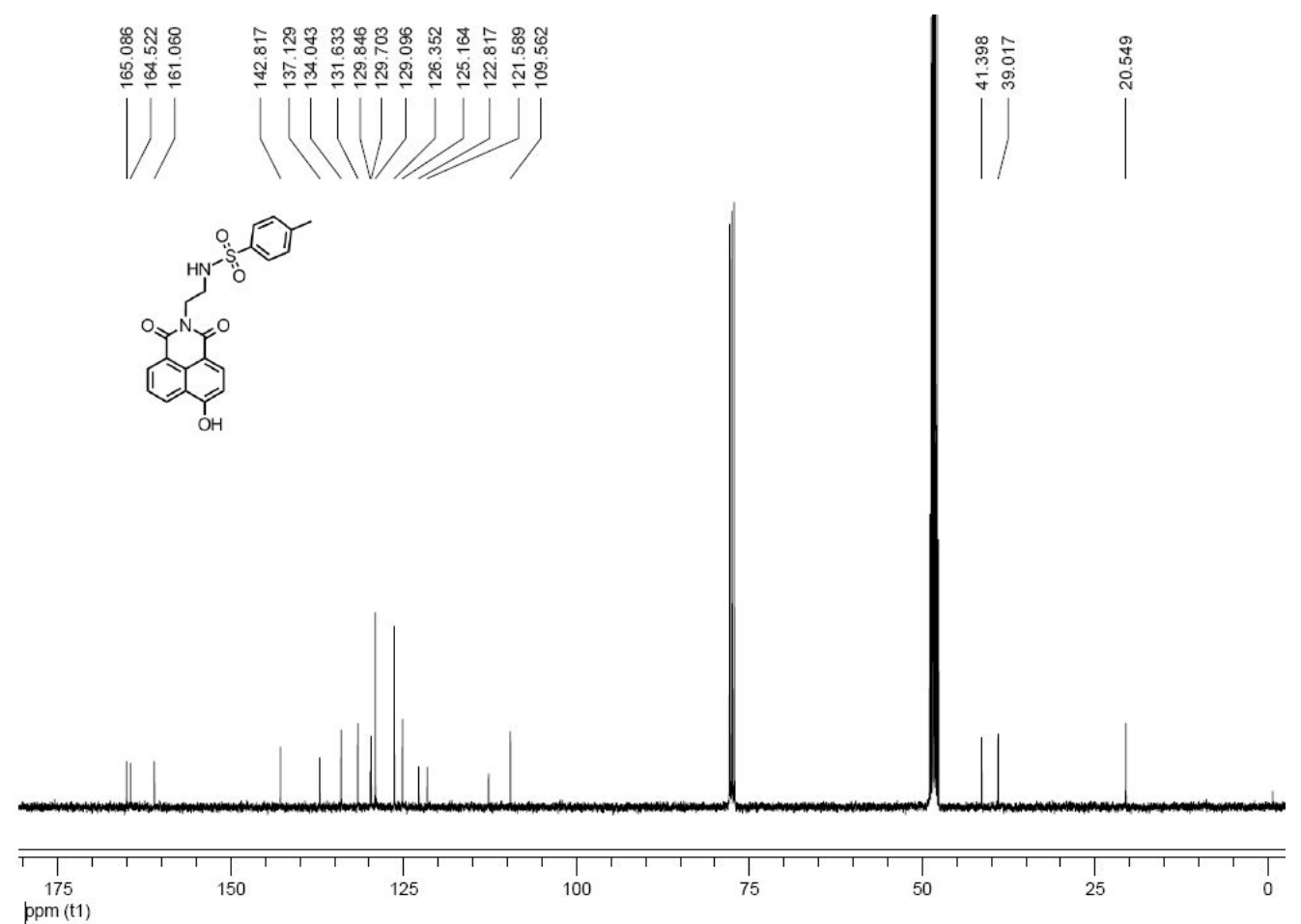

Figure S12 ${ }^{13} \mathrm{C}$ NMR data of compound Nap-OH $\left(\mathrm{CDCl}_{3}: \mathrm{MeOD}, \mathrm{V}: \mathrm{V}=1: 1\right)$. 


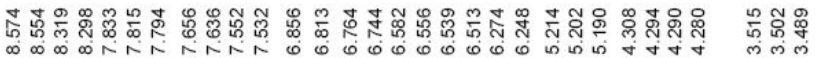

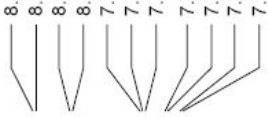
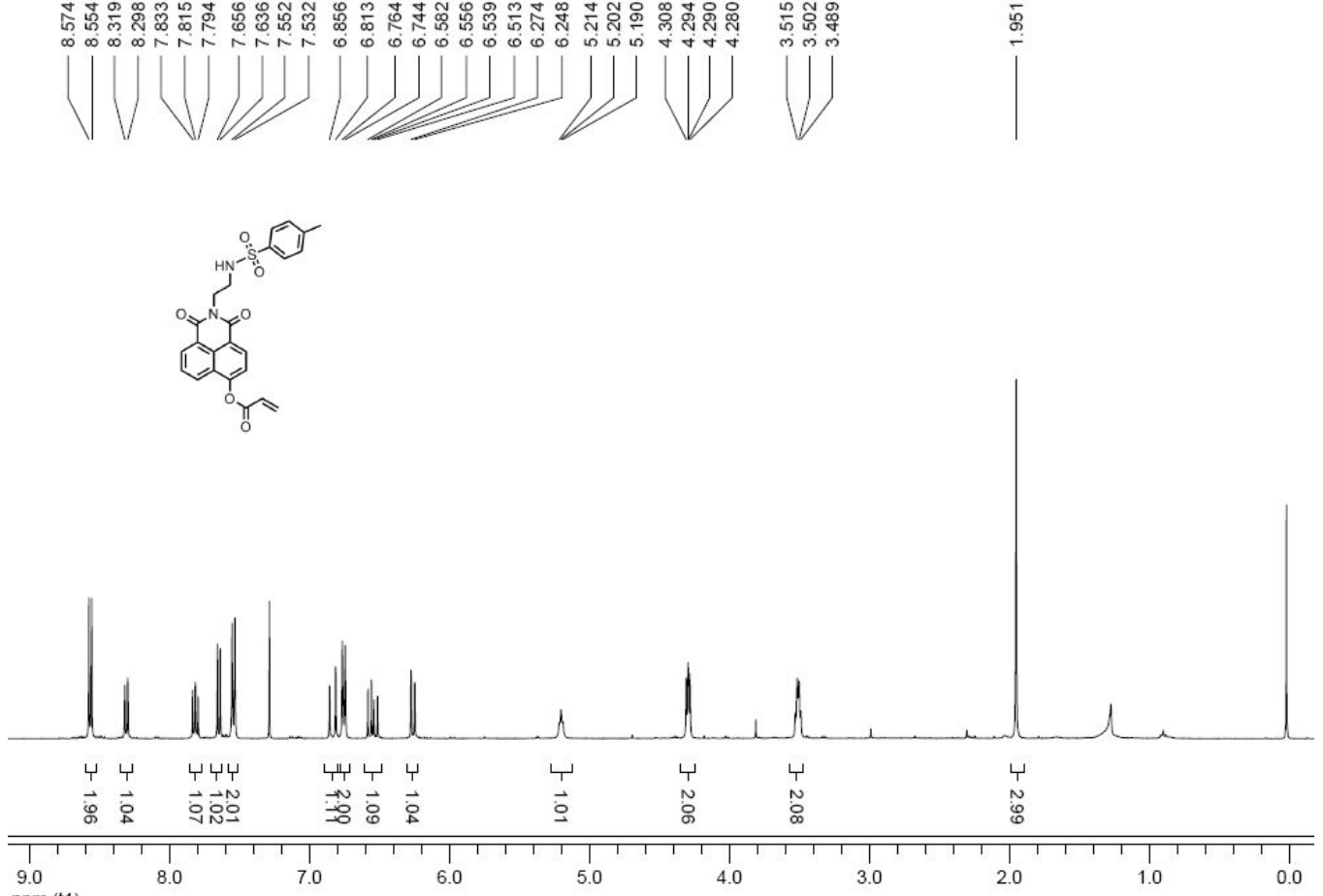

ppm (t1)

Figure $\mathbf{S 1 3}{ }^{1} \mathrm{H}$ NMR data of the probe Nap-Cys $\left(\mathrm{CDCl}_{3}\right)$.
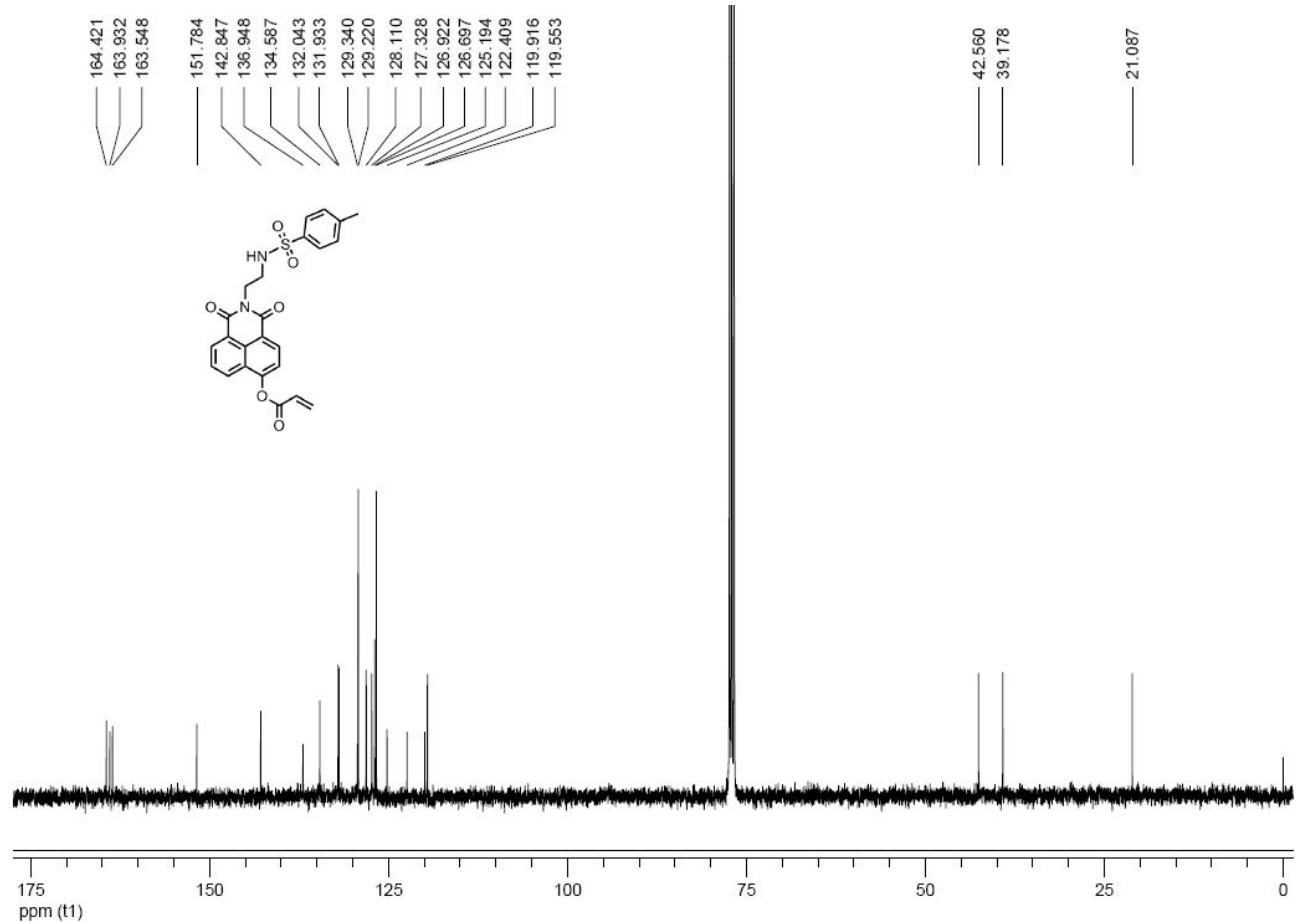

Figure $\mathbf{S 1 4}{ }^{13} \mathrm{C}$ NMR data of the probe Nap-Cys $\left(\mathrm{CDCl}_{3}\right)$. 
(A) HPLC data

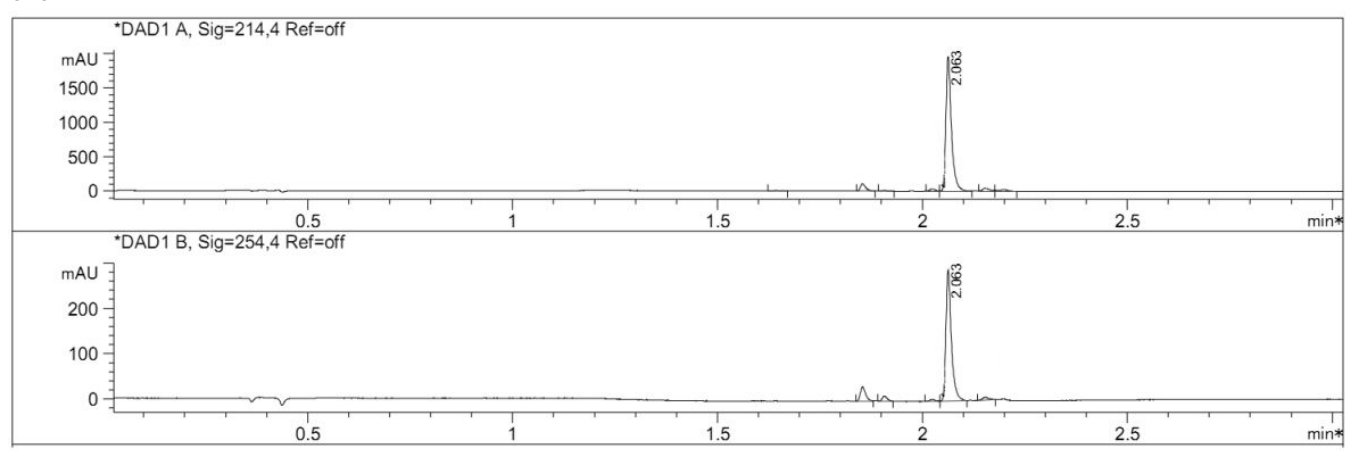

(B) MS data

Ret. Time: 2.06

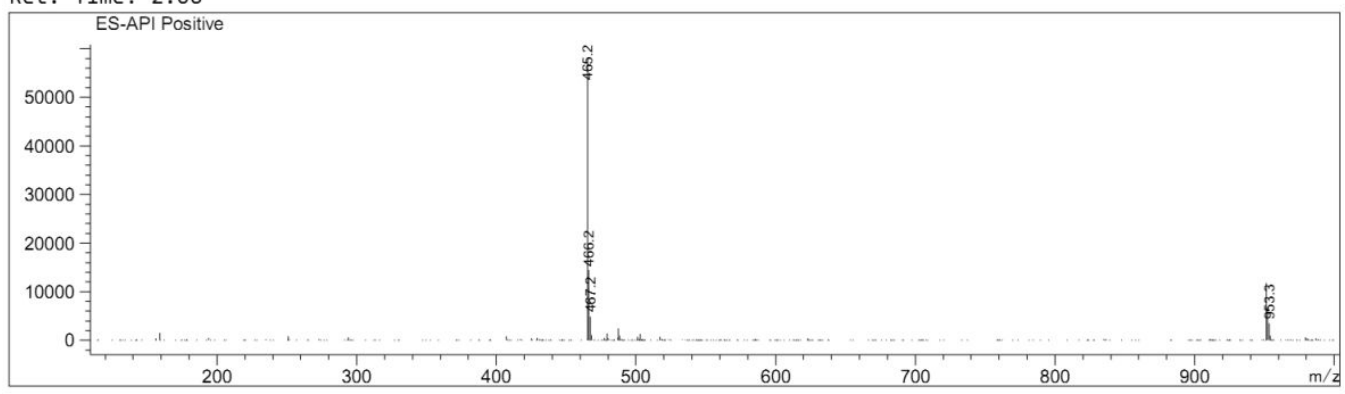

Figure S15 LC-MS data of the probe Nap-Cys.

Reference:

1. Zhang, N.; Dong, B.; Kong, X.; Song, W.; Lin, W. A two-photon endoplasmic reticulum-targeting fluorescent probe for the imaging of $\mathrm{pH}$ in living cells and zebrafish. Anal. Methods, 2018, 10, 5702-5706 . 